\title{
Federica Marsico
}

UNIVERSITY OF PAVIA

\section{A Queer Approach to the Classical Myth of Phaedra in Music}

\section{The Topic}

In the second half of the 2oth century, the myth of Phaedra, according to which the wife of King Theseus of Athens desperately falls in love with her stepson Hippolytus, was set to music by three homosexual composers in the following works: the dramatic cantata Phaedra for mezzosoprano and small orchestra (1976) by Benjamin Britten (1913-1976) after a text by the American poet Robert Lowell, the opera Le Racine: pianobar pour Phèdre (1980) by Sylvano Bussotti (1931) after a libretto drafted by the Italian composer himself and consisting of a prologue, three acts, and an intermezzo, and, last but not least, the two-act concert opera Phaedra (2007) by Hans Werner Henze (1926-2012) after a libretto by the German poet Christian Lehnert. ${ }^{1}$

1 In the second half of the century, other musical adaptations of the myth were also composed, namely the one-act opera Phèdre by Marcel Mihalovici (1898-1986) after a text by Yvan Goll and consisting in a prologue and five scenes (1951), the chamber opera Syllabaire pour Phèdre by Maurice Ohana (1913-1992) after a text by Raphaël Cluzel (1968), and the monodrama Phaedra for mezzo-soprano and orchestra by George Rochberg (1918-2005) after a text by Gene Rosenfeld (1976). 
This paper summarizes the results of a three-year research project $(2013-2015)^{2}$ that has proved that the three above-mentioned homosexual composers wilfully chose a myth consistent with an incestuous-and thus censored-form of love in order to portray homoerotic desire, which the coeval heteronormative society of course labelled as deviant and hence condemned.

\section{Theoretical References}

The theoretical references of this research are gender studies and queer theory. When gender studies was developed in the United States midway through the 7os, it led to the further evolution of gender-related research tendencies of cultural studies. The latter introduced the academic reflection on the relationship between individual and social normative structures. The creative dimension can also be interpreted as a result of confrontation between collectively shared values and individual visions. Gender acquired particular significance among those factors playing a crucial role in the conflict between the individual and the dominant culture. As a consequence, gender studies annihilated the essentialist vision of sexual identities and began to consider them as complex socio-cultural formations.

Queer theory developed from gender studies in the 9os in the United States. It redefined the previously pejorative term "queer", and used it as a term that embraces all non-heterosexual identities. Teresa de Lauretis, one of the pioneers of queer theory, explains the new meaning of the word in a famous article from 1991:

\footnotetext{
Today we have, on the one hand, the terms "lesbian" and "gay" to designate distinct kinds of life-styles, sexualities, sexual practices, communities, issues, publications, and discourses. [...] In a sense, the term "Queer Theory" was arrived at the effort to avoid all of these fine distinctions in our discursive protocols, not to adhere to anyone of the given terms, not to assume their ideological liabilities, but instead to both transgress and transcend them-or at the very least problematize them. ${ }^{3}$
}

2 F. Marsico, Una lettura queer del mito di Fedra. Gli adattamenti di Britten, Bussotti e Henze, PhD dissertation, University of Pavia 2016.

3 T. de Lauretis, Queer theory. Lesbian and gay sexualities. An introduction, "Differences" III (1991), 2, pp. III-XVIII: V. 
Together with de Lauretis' definition, the writings by Eve Kosofsky Sedgwick and Judith Butler represent the theoretical grounding of queer studies. In her book Epistemology of the Closet (1990), Kosofsky Sedgwick displays the dynamics of "the closet", i.e. the condition of a homosexual who must continuously renegotiate their individual needs with the surrounding heteronormative context. ${ }^{4}$ Kosofsky Sedgwick underlines that the condition of secrecy of homosexuality does not end with the act of coming out of the closet, but can persist in the individual also afterwards. As a consequence, literary writing can offer expression to the homosexual identity through the use of an intentionally ambiguous language.

In the same year, Butler published a book titled Gender Trouble, ${ }^{5}$ in which the American philosopher delved into the debate about the social construction of gender. In her successive book, Bodies That Matter (1993), Butler further explained her ideas: she affirms that chauvinist hegemony is the consequence of the heterosexual hegemony that defines male and female norms. This hegemony causes the condemnation of the sexualities that transgress the norm, and the emergence of a homophobic regime. The existence of all excluded sexualities is, however, essential for the subsistence of heterosexuality. Namely, they define the boundaries within which the bodies that materialize the norm can be considered as "bodies that matter", that is, as bodies that are socially recognized. ${ }^{6}$

In the 8os, American musicology opened up to gender studies and began to consider musical discourse as a space for the narration of identities. Various pioneering studies prepared the ground for the consolidation of this new critical approach. Among these, two are universally known: the papers by Philip Brett about the opera Peter Grimes (1945) by Britten, interpreted as the allegory of the oppression of a homosexual, ${ }^{7}$ and by Maynard Solomon about the dissemination of homoeroticism in the Viennese milieu frequented by Franz Schubert. ${ }^{8}$ Research outcomes in the field of the queer musicology have abundantly demonstrated that the queer approach permits shedding light on some aspects of the musical work that would be otherwise ignored by both

\footnotetext{
E. Kosofsky Sedgwick, Epistemology of the Closet, Berkeley 1990.

J. Butler, Gender Trouble. Feminism and the Subversion of Identity, New York 1990.

J. Butler, Bodies That Matter. On the Discursive Limits of "Sex", New York 1993, p. 16.

P. Brett, Britten and Grimes, "The Musical Times" cxviII (1977), 1618, pp. 955-10oo.

M. Solomon, Franz Schubert and the peacocks of Benvenuto Cellini, "19th-Century Music" XII (1989), 3, pp. 193-206.
} 
scholars and the audience..$^{9}$ A gender-oriented approach has not yet been applied to Henze's and Bussotti's works. On the contrary, the expression of homosexuality in Britten's oeuvre was deeply investigated not only by Brett who, after the above-mentioned essay, wrote other numerous essays on this topic, ${ }^{10}$ but also by other scholars.

In many writings about music and gender, there is evident lack of a univocal and systematic approach. Regarding this aspect, Brett proclaims one of the cornerstones of the queer musicology in his presentation to Queering the Pitch (1994), the first collection of essays that aim to eliminate the latent homophobia in the musicological research. ${ }^{11}$ Brett states that:

\footnotetext{
A reader who expects a new kind of musicology, moreover, must inevitably be disappointed by the lack of a unified approach, a single or even systematic method. To queer the pitch is to get rid of such notions. ${ }^{12}$
}

It is possible, however, to identify some common ideas on which queer musicology is founded. Firstly, the musical work is considered as a result of a cultural process and, consequently, the analysis of it is extended to the context in which the work is produced. Secondly, great importance is given to the subjectivity of the composer and to the ex-

9 The musicological literature on the topic is substantial. See, among others: S. McClary, Feminine Endings. Music, Gender, and Sexuality, 2nd ed., MinneapolisLondon 2002; L. Kramer (ed.), "19th-Century Music" xvii (1993), 1: Schubert. Music, Sexuality, Culture; id., Franz Schubert. Sexuality, Subjectivity, Song, Cambridge 1998; R. A. Solie (ed.), Musicology and Difference. Gender and Sexuality in Music Scholarship, Berkeley-Los Angeles-London 1993; P. Brett, Piano four hands. Schubert and the performance of gay male desire, "19th-Century Music" XII (1997), 2, pp. 149-176; P. Brett, E. Wood, G. C. Thomas (eds.), Queering the Pitch. The New Gay and Lesbian Musicology, 2nd ed., New York 2006; J. Kallberg, Chopin at the Boundaries. Sex, History, and Musical Genre, Cambridge-London 1996; E. T. Harris, Handel as Orpheus. Voice and Desire in the Chamber Cantatas, Cambridge MA 2001; N. Hubbs, The Queer Composition of America's Sound. Gay Modernists, American Music, and National Identity, Berkeley 2004; P. Attinello, D. Osmond-Smith, Gay Darmstadt. Flamboyance and rigour at the summer courses for new music, "Contemporary Music Review" XxVI (2007), 1, pp. 105-114.

10 Some of them are collected in: P. Brett, Music and Sexuality in Britten. Selected Essays, Berkeley-Los Angeles-London 2006.

11 P. Brett, E. Wood, G. C. Thomas (eds.), Queering the Pitch, op. cit.

12 P. Brett, Are you musical? Is it queer to be queer? Philip Brett charts the rise of gay and lesbian musicology, "The Musical Times" CIIIV (1994), 1816, pp. 370-376: 373. 
pression of it in their works. Finally, musical discourse is considered as more favourable in comparison to the external world for the expression of queer identities, and for bringing into question social prejudices.

\section{Preliminary Observations}

Some preliminary observations on the myth of Phaedra proved very useful in analysing the three works from a homosexual perspective.

A careful review of the myth's most famous literary elaborations makes it possible to identify the aspects of it that affect gay sensibility. ${ }^{13}$ For instance, the fact that Euripides links Phaedra's desire with

13 In this phase of the research the reference literary studies have been: R. Barthes, Sur Racine, Paris 1963; L. Spitzer, Linguistics and Literary History. Essays in Stylistics, 2nd ed., Princeton 1967, pp. 87-134; F. De Sanctis, La Fedra di Racine, in: G. Contini (ed.), Scelta di scritti critici e ricordi, Torino 1969, pp. 71-91; J.-P. Vernant, P. Vidal-Naquet, Mythe et tragédie en Grèce ancienne, Paris 1972, and Mythe et tragédie deux, Paris 1986; B. Snell, Die Entdeckung des Geistes. Studien zur Entstehung des europäischen Denkens bei den Griechen, 4th ed., Göttingen 1975, pp. 95-110; R. Uglione (ed.), Atti delle Giornate di studio su Fedra (Torino, 7-9 maggio 1984), Torino 1985, pp. $33-54$ (M. Guglielminetti, La Fedra di d'Annunzio, e altre Fedre), 55-77 (G. Paduano, Ippolito. La rivelazione delleros), 79-96 (O. Longo, Ippolito e Fedra fra parola e silenzio), 113-131 (G. Rosati, Forma elegiaca di un simbolo letterario. La Fedra di Ovidio), 143-212 (F. Giancotti, Poesia e filosofia in Seneca tragico. La Fedra), 213-236 (A. M. Scarcella, Gli amori di Fedra fra tragedia e romanzo), 241-254 (D. Dalla Valle, Classicità della Phèdre di Racine), 257-261 (G. Raboni, Lo statuto della reticenza); D. Dalla Valle, Il mito cristianizzato. Fedra/Ippolito e Edipo nel teatro francese del Seicento, Bern 2006; N. Fusini, La Luminosa. Genealogia di Fedra, Milano 1990; F. Orlando, Due letture freudiane. Fedra e Il misantropo, Torino 1990; V. Di Benedetto, Euripide. Teatro e società, Torino 1992; J. Starobinski, L'oil vivant. Corneille, Racine, La Bruyère, Rousseau, Stendhal, Paris 1999, pp. 71-92; M. Bettini, L'incesto di Fedra e il corto circuito della consanguineità, "Dioniso" (2002), 1, pp. 88-99; F. Carpanelli, Frammenti tragici. Euripide e l'incesto, in: G. Guidorizzi (ed.), Legami di sangue, legami proibiti. Sguardi interdisciplinari sull'incesto, Roma 2007, pp. 31-52; S. Mattiacci, Da Apuleio all'Aegritudo Perdicae. Nuove metamorfosi del tema di Fedra, in: R. Degl'Innocenti Pierini, N. Lambardi, E. Magnelli et al. (eds.), Fedra. Versioni e riscritture di un mito classico. Atti del convegno AICC (Firenze, 2-3 aprile 2003), Firenze 2007, pp. 131-156; G. Nuzzo, La Dea Bianca e il Cacciatore. Fedra tra Seneca e d'Annunzio, in: M. Blancato, G. Nuzzo (eds.), La tragedia romana. Modelli, forme, ideologia, fortuna, Palermo 2007, pp. 77-107; V. Borghetti, Fedra. La Grecia modernista di d'Annunzio e di Pizzetti, in: G. Sandrini, M. Natale (eds)., Gli antichi dei moderni. Dodici letture da Leopardi a Zanzotto, Verona 2010, pp. 139-168. 


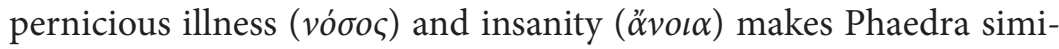
lar to a homosexual whose sexuality is viewed as a disease in many modern cultures. On the other hand, in Jean Racine's version of the myth Euripides' vision of Phaedra's mistaken desire connects to the Christian reading of her desire as a sin, which in turn equates the protagonist to the epitome of a homosexual as demonized by homophobic Christianity: as in the case of Phaedra, homosexuals embody a sinful deviance and shall thus be guided through a path of penitence and redemption. The myth's fortune throughout the centuries is fully consistent with its representation of an erotic theme transgressing bans-both ethical and legal. Phaedra's love and homosexual love are tragically unutterable; both are viewed as obscene and indecorous, and can thus not even be mentioned.

Before the three works were analysed at all, I investigated how Britten, Bussotti and Henze experienced their own homosexuality and gave utterance to it in their other compositions. ${ }^{14}$

Britten began reckoning with his homosexuality after his twenties. His decision to embark on his first and only relationship with an adult man, namely the famous tenor Peter Pears, did not extinguish his attraction to adolescents that was constant during his life. In a letter from 1942, the poet and Britten's close friend Wystan Hugh Auden reflected on Britten's self-censure of his homosexuality and defined his attraction to young boys as a symptom of it. ${ }^{15}$ Britten's sexual prudery, which caused the breaking up of his friendship with Auden, emerged also in his relationship with Pears. Britten was so prudish that he did never use in public the term "gay" and avoided socializing with homosexual

14 The following works have been considered: L'Enfance from Quatre chansons françaises (1928), Antique from Les Illuminations (1940), Hymn to St. Cecilia (1942), The Trees They Grow So High (1943), The Turn of the Screw (1954), A Midsummer Night's Dream (1960), The Burning Fiery Furnace (1968), and Who Are These Children? (1971) by Britten; Boulevard Solitude (1951), König Hirsch (1956), Der Prinz von Homburg (1960), Elegy for Young Lovers (1961), Gogo no eiko (1963), Der junge Lord (1965), The English Cat (1983), and Die Upupa und der Triumph der Sohnesliebe (2003) by Henze; Nottetempo con lo scherzo e una rosa (1953-57), Due voci (1958), Pièces de chair II n. 1 (1958), La Passion selon Sade (1965), Mit einem gewissen sprechenden Ausdruck (1965), Syro Sadun Settimino (1974), Nudi per flauto e fiati gravi (1981), and Nuit du faune (1990-1991) by Bussotti.

15 D. Mitchell, P. Reed (eds.), Letters from a Life. The Selected Letters of Benjamin Britten 1913-1976, vol. 2, London 1998, pp. 1015-1016. On the relationship between Britten and children see: J. Bridcut, Britten's Children, London 2006. 
couples. Pears, on the other hand, was more uninhibited and showed himself often annoyed at Britten's vulnerability about sexual matters (for this reason, he sometimes satisfied his sexual desires elsewhere, during his tournées far from his partner). ${ }^{16}$

The overcoming of Britten's sexual inhibition was not favoured by the coeval social context. While he was emerging as British composer, homophobia was very widespread within English public opinion, and the discriminatory law prosecuting homosexuality - that was in force until 1967-supported it. In the 50s, Britten, who was born less than twenty years after Oscar Wilde's sentence, fell victim to homophobia of some English composers envious of his success and of some managers of nationally important cultural institutions. When he began to deal with the theme of sexuality in his operas, he was aware of the fact that he acted in a minefield. The government censorship was in force until 1968, and the composer had to obtain Lord Chamberlain's approval for all his operas from Peter Grimes (1945) to Midsummer Night's Dream (1960). Only after the decriminalisation of homosexuality Britten felt more free to deal with that theme, also by virtue of the fact that he was awarded the Order of Merit in 1965 by the Royal Family, who in 1967 attended the inauguration of the new theatre of the festival founded by the composer in Aldeburgh. Moreover, Britten's collaboration with homosexual writers (such as Edward Morgan Forster, the author of Billy Budd's libretto) enabled him to treat controversial themes through a cryptographic language in order not to incur censorship.

Henze experienced his adolescence during the consolidation of the Third Reich, when the pre-existing homophobic law (the debated paragraph 175 of the German Criminal Code) was tightened, and during the war many homosexuals were identified with a pink triangle and deported to the concentration camps. The penalisation of homosexuality was in force in West Germany until 1969 (in East Germany until 1948) and during the postwar period the composer happened to be interrogated together with his Calabrian partner by Constance's police after their householder lodged a complaint against them. ${ }^{17}$ Henze's

16 P. Kildea, Benjamin Britten. A Life in the Twentieth Century, London 2013.

17 The episode happened during the winter of either 1948 or 1949. See: H. W. Henze, Die Schwierigkeit, ein bundesdeutscher Komponist zu sein. Neue Musik zwischen Isolierung und Engagement (interview with Hubert Kolland), in: H. W. Henze, Musik und Politik. Schriften und Gespräche 1955-1984, new ed., München 1984, pp. 300-331: 323. 
choice to definitively move to Italy in 1953 was therefore closely related to his desire to escape homophobia in his native country, according to what he explained in his autobiography, when he recalled the first hours spent in his new house on the island of Ischia in southern Italy. ${ }^{18}$

Henze's need to live freely his homosexuality underpinned his choice to collaborate for his operas with writers sensitive to gender matters (in some cases declared as homosexual, i.e. Hans Magnus Enzensberger, Gastón Salvatore Pascal, Wystan Hugh Auden and Chester Kallman), and to opt for literary subjects that lend themselves to being read from a queer perspective (such as Yukio Mishima's romances and Heinrich von Kleist's dramas). Henze himself in an interview of 1991 explained that the theme of homosexuality is constantly present in his works. ${ }^{19}$ Moreover, he lived openly his long-lasting relationship with Fausto Moroni, his partner since the 6os. However, because of the lack of sources we can reconstruct very little about it. At the Paul Sacher Foundation of Basel, where the composer's archive is stored, very little of the correspondence between him and his partner survives.

Bussotti differs from his two colleagues because since his debut he centred his art on the expression of erotic sphere. One example will be sufficient to clarify this aspect. His operatic debut was La Passion selon Sade (1965), defined by him as a "mystère de chambre avec tableaux vivants". ${ }^{20}$ Its title's reference to the Marquis de Sade, and the use of an erotic sonnet by the sixteenth-century poetess Louise Labé ${ }^{21}$ as libretto are only some of the aspects through which the eroticism that pervades the whole composition expresses itself. In Bussotti's reworking of the female love lament that the poem deals with, the in-love woman takes on the traits of some sadomasochistic romances main characters, namely Ô, the young sex slave of Pauline Réage's erotic romance Histoire d'Ô, edited in France eleven years before La Passion selon Sade, ${ }^{22}$ and the two sisters Justine and Juliette, who symbolize respectively virtue and vice in De Sade's romances. Thanks to the overlapping of different fe-

18 H. W. Henze, Reiselieder mit böhmischen Quinten. Autobiographische Mitteilungen 1926-1995, Frankfurt am Main 1996, p. 151.

19 D. Daolmi, Henze ovvero della coerenza (interview with the composer), "Babilonia" 89 (1991), pp. 42-44.

S. Bussotti, La Passion selon Sade. Mystère de chambre avec Tableaux vivants, précédé de Solo avec un couple Rara et suivi une autre Phrase à trois (score), Milano 1966.

21

L. Labé, Euvres complètes, ed. by E. Giudici, Genève 1981, p. 142.

22

P. Réage, Histoire d'O, preface by J. Paulhan, Paris 1954. 
male roles linked to eroticism, La Passion's main character embodies different sexual instincts that the singer interprets through different inflections of her voice. When she enters wrapped up in a cape, she is not able to pronounce words in full, but then she gradually shows her sensuality and gives free play to her rising erotic desire, while she looks lasciviously for her beloved's body. ${ }^{23}$

The close connection between musical gesture and eroticism, as well as the theme of homoeroticism investigated in relation both to its hedonistic component and to the repression of it within the heteronormative social context, feature many other Bussotti's compositions. Moreover, the artist showed a strong interest for the writings of some homosexual artists and intellectuals of his age, who often are either the dedicatees of his works or the authors of the texts set to music. Among them, we can mention Alain Daniélou (a guru of the relation between religion and eroticism in the Oriental civilizations), Aldo Braibanti (an Italian writer who was a victim of judicial persecution in 1968 because of his homosexuality), and Filippo de Pisis (pseudonym of Luigi Filippo Tibertelli, a writer and a painter who never made secret of his homosexuality, and flaunted it also during the Fascist era, when many homosexuals were interned since considered as "invert").

\section{The Works}

Before undertaking the musical analysis of the three works, all compositions of the three artists were examined from the perspective of connections between the mythical subject and the theme of homoeroticism as well as of the sphere of sexuality coming to expression. ${ }^{24}$ They were compared to their historical context, marked by widespread homophobia and utterly homophobic legislation. ${ }^{25}$ In order to most

23 S. Bussotti, La Passion selon Sade, op. cit., pp. $6 \mathrm{ff}$.

24 The following works have been considered: Young Apollo (1939), Calypso from Cabaret Songs (1939), Six Metamorphosen after Ovid (1951), and Death in Venice (1973) by Britten; Apollo et Hyazinthus (1949), Labyrinth (1952), The Bassarids (1966), Orpheus (1979), and Venus und Adonis (1997) by Henze; Früher Apollo from Quattro ricordi di Rilke (1950), Rara Requiem (1969), Nottetempo (1976), Voliera (1986-89), and Ermafrodito (1999) by Bussotti.

25 On historical context see: J. Weeks, Coming Out. Homosexual Politics in Britain from the Nineteenth Century to the Present, London-New York 1990; 
accurately detect the three artists' longing to out their homosexual sensibility, we put the adaptations of Phaedra's myth into the perspective of artistic production in its broader sense, thus including both mythical and non-mythical subjects.

\section{BRITTEN'S PHAEDRA}

The text of Britten's Phaedra, taken from Lowell's translation of Racine's tragedy Phèdre, ${ }^{26}$ consists of four confessions of Phaedra, while all other characters of the tragedy are eliminated. After the archival material from the Britten-Pears Foundation was inspected, special care was devoted to the theme of the repressed love that engenders the protagonist's pain. Various musical motives were identified that help define the protagonist's inner conflict between her instinct to follow her feelings and the inhibition imposed by her rationality. The motives are first presented in the prologue, where Phaedra tells how she fell in love with her stepson, and further employed in her love declaration to Hippolytus. One of these motives is, for instance, a five-note descending one, which is associated to the self-censure of desire and is highlighted in a box in the examples that follow: ${ }^{27}$

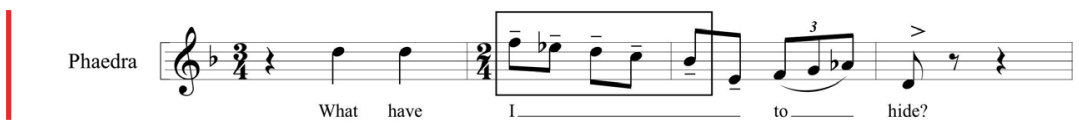

Ex. 1: B. Britten, Phaedra, bb. $62-65$.

G. Goretti, T. Giartosio, La città e l'isola. Omosessuali al confino nell'Italia fascista, Roma 2006; M. Schwartz (ed.), Homosexuelle im Nationalsozialismus. Neue Forschungsperspektiven zu Lebenssituationen von lesbischen, schwulen, bi-, transund intersexuellen Menschen 1933 bis 1945, München 2014.

26 R. Lowell, Racine's Phèdre. Phaedra, Faber 1961.

27 The musical examples are taken from: B. Britten, Phaedra. Dramatic Cantata for Mezzo-Soprano and Small Orchestra Op. 93. Words from a Verse Translation of Racine's Phèdre by Robert Lowell (score), London 1992. 


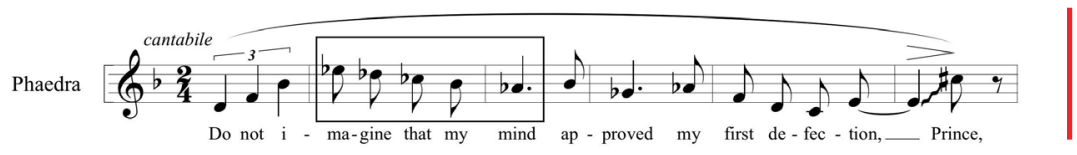

Ex. 2: B. Britten, Phaedra, bb. 92-97.

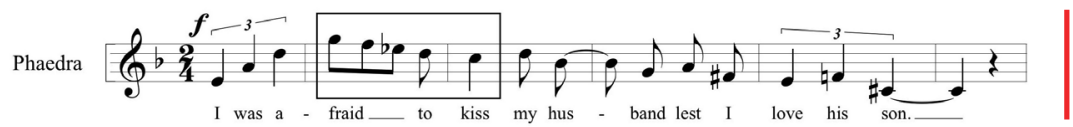

Ex. 3: B. Britten, Phaedra, bb. 129-134.

A musical analysis performed on those motives warranted suggesting that the composer identified with the character of Phaedra. The words of the protagonist, who is in love with a man who is much younger than she is, may have given utterance to Britten's difficulty in freeing himself from the dynamics of the closet, which in turn fostered his interest in men much younger than himself.

However, the mythical subject is a well-suited topic for drawing a universal message from Britten's individual experience. Some observations by the French semiotician Roland Barthes proved useful in construing the myth accordingly. ${ }^{28}$ Barthes defines Racine's hero as one who refuses his fathers' will, and aims to establish a new nomos where each individual wish is within reach. This liberating effort is achieved through the logos, just as in the cantata, where Phaedra resorts to no tangible action, but merely gives voice to the interior conflict between her impulse to speak about her desire, and the frustration thereof.

It was possible, therefore, to read Phaedra's monologue as an expression of what Barthes defines "conscience parlée de la division" ${ }^{29}$ between the instinct to experience her sexual desire freely on the one hand, and self-censure on the other. This "drame panique de louverture" 30 unraveling within Phaedra relates her to a homosexual individual who struggles between concealing his feelings and letting them loose through the logos, i.e. through the action of coming out.

28 R. Barthes, op. cit.

29 Ibid., p. 1014.

30 Ibid., p. 1066. 
In the cantata, however, the expression of gayness is much more veiled compared to the ones that can be found in the operas deemed most indicative of Britten's homosexual aesthetics, such as Billy Budd (1951), The Turn of the Screw (1954), or Death in Venice (1973), ${ }^{31}$ focusing on the ambiguous relationship between two men. On the contrary, in Phaedra a single female character experiences a forbidden heterosexual love. The important study by Lloyd Whitesell on Britten's homosexual aesthetics highlights, however, Britten's cryptographic approach to include the theme of queer sexuality into his operas, the approach aiming to extend the chance of reflecting on homosexuality to those ignoring or downplaying its existence. He writes:

\footnotetext{
I propose that Britten's music dramatizes a deviant or marginal perspective in fundamental and unforeseen ways. [...] Even if certain listeners remain unaware of the specific queer meanings encoded in the operas, I argue, they must still come to grips with the general structures of deviant subjectivity that make the works so compelling in the first place. As I hope to show, central preoccupations for Britten are the confrontation of different perspectives and the possibility of creating bonds of identification across incompatible positions. ${ }^{32}$
}

It could therefore be maintained that the composer's choice to encrypt his discourse on gayness in the cantata was aimed at eliciting two possible interpretations among its audience, which may either fully grasp the analogy between Phaedra's condition and that of a gay individual, or ignore this reading but still become acquainted with the feelings of a person whose sexuality is judged as deviant.

\section{BUSSOTTI'S PHÈDRE}

As to Bussotti's opera, also based on Racine's tragedy, the press review of the premiere was analysed first. ${ }^{33}$ Its explicit reference to the theme of homosexuality is the main reason why the opera was little appreciated by its critics. Three aspects of the opera were examined in order to understand how the artist's sexual identity comes to expression in

31 See: P. Brett, Music and Sexuality in Britten, op. cit., passim.

32 L. Whitesell, Britten's dubious trysts, "Journal of the American Musicological Society" (2003), 66, pp. 637-694: 643.

33 It is stored in the Archivio storico documentale of the Teatro alla Scala in Milan. 
it: the setting, the elaboration of the literary source, and some aspects of the twelve-note composition.

In the opera, Racine's tragedy unravels in a small Parisian piano bar called "Le Racine", which is actually a brothel for male clients, Madame Phèdre being its owner and Hippolyte an alluring gigolo. Analysis of the libretto shows Racine's verses as being de-contextualized, and acquiring a new significance within the opera. ${ }^{34}$ This elaboration is designed for various purposes: firstly, to portray Hippolyte's character as being desired not only by his stepmother, but all of the brothel's male clients; secondly, to describe homoerotic pleasure (for instance, the words with which Phèdre accuses Hippolyte of raping her are used in the second act to describe a male sadomasochistic orgy); ${ }^{35}$ finally, to turn the original tragedy's heterosexual incest into a homosexual one. The latter result is achieved by adding the character of Hippolyte's father, who is in love with his son. His name however is not Theseus, but Jean Racine, just as the author of the tragedy. Moreover, Bussotti employs some dodecaphonic devices to describe Hippolyte's distance from women on the one hand, and his being attracted to his father and men in general on the other. For instance, Phèdre's musical row imitates Hippolyte's one at the beginning of the opera only to gradually distance itself from it in the episodes that follow. ${ }^{36}$

Based on the analysis of the work, it can be argued that in his elaboration of the myth, Bussotti portrays the carnality of homoerotic desire, and, more generally, a utopian universe where homosexuality is free to express itself. In the opera, the brothel clients' desire towards Hippolyte takes on much greater importance in comparison to Phaedra's desire. Moreover, homoerotic desire is represented there without any reference to the ideas of abnormality or guilt. The opera Le Racine therefore

34 The libretto was never published by the composer. It is now available in: F. Marsico, Una lettura queer del mito di Fedra, op. cit., pp. 219-252.

35 Act II, scene 1.

36 For instance, if we compare Hippolyte's row (Act I, scene 1: $\left[C^{\prime}-D^{\prime}-A\right]-\left[E^{\prime}-G^{\prime}-F^{\prime}\right]-[B$ flat-G flat-D flat-E flat-A flat-B]) with Madame Phèdre's first row (Act I, scene 2: [ $\left.A^{\prime}-D^{\prime}-C^{\prime}\right]-\left[E^{\prime}\right.$ flat-G' flat-F] $\left[B-A^{\prime}\right.$ flat- $D^{\prime \prime}$ flat-B' flat-G'-E]), the derivation of the latter from the former is evident. Madame Phèdre's row can be subdivided into two groups of three notes ( $a$ and $b$ ) and one group of six notes (c). The group $a$ is the retrograde form of the first group from Hippolyte's row, while the group $b$ derives from the second group of Hippolyte's row, but with the first two notes lowered of a halftone. The group $c$ links up to the previous group through a triton instead of a fifth like in Hippolyte's row. Its opening interval ( $B-A$ ' flat) seems to herald the retrograde form of the group $c$ from Hippolyte's row, but it actually introduces four sounds from the diminished seventh of $\mathrm{E}$ minor. 
belongs to Bussotti's musical aesthetics, focused on the visual exaltation of the carnality of desire as well as on the uninhibited exhibition of the body and its passions. ${ }^{37}$

\section{HENZE'S PHAEDRA}

Henze's opera offers yet a third possible interpretation of the myth from the homosexual point of view. After the study of the opera's genesis and the libretto's sources, the feelings of the character Hippolytus were drawn from the analysis of the poetic and musical discourse, and his character was identified as the expression of a queer identity.

Although the opera is called Phaedra, Hippolytus is the main character. Over the course of the story, he experiences a process of emancipation. Initially, he presents himself as a hunter who loves the woods, serves the goddess Artemis and is indifferent to love; ${ }^{38}$ yet in the second act but he is born to a new life, affirms his own autonomy, and is crowned king of the woods.

Neither the tragedy of his stepmother's guilt nor her erotic desire towards her stepchild is in the foreground here; the focus is rather put on Hippolytus' homosexuality. Euripides' characterisation of Hippolytus as a misogynist who is also devoted to Artemis presents Henze with an opportunity to portray an individual whose sexuality does not conform to the norms. Hippolytus' experience as a gay man is, however, positive, as he understands his gayness and manages to assert it in front of others. The happy ending (an original twist if compared to the myth) sanctions the achievement of this goal. Artemis ushers the man through this journey of self-discovery, and contributes to defining her protégés sexuality, as her role is performed by a countertenor. The vocal role not only reflects the goddess' masculine traits, but also highlights the fact that the relationship between her and Hippolytus is featured on stage as one between two men. Their close relationship is proved by the fact that during his first solo (Act I, scene 2) Hippolytus describes himself as deeply attached to the goddess, whose eyes follow

37 On this aesthetics see: L. Scarlini (ed.), Corpi da musica. Vita e teatro di Sylvano Bussotti, Firenze 2010.

38 His first words in the opera are the following: "Ich trete in die Schatten der Akazienbäume, | in ihre ersten langgestreckten Schatten am Morgen, | um meinen Fluchtpunkt zu finden: den fließenden | Atem des Waldes und die Gerade des Pfeils" (Act I, episode 2). 
him everywhere (he says "Sie schaut mich an von allen Seiten"); then, in the second act Artemis reassembles in her temple the torn pieces of Hippolytus' body and brings him back to life, but hard upon she cages him in order to keep him close to her for ever.

As in other works by Henze, ${ }^{39}$ gayness is represented in this opera by means of cryptographic language. Those among the audience who don't understand it will interpret the opera as a mere adaptation of Phaedra's myth. If this double interpretation seems to link Henze's opera to Britten's cantata, it is however clear that the former is devoid of any reference to a sexuality judged as deviant, as the purpose of the German composer, different from Britten's, is to present gayness in rather positive terms.

\section{Final Observations}

The examination of the three works shows that the three composers chose different ways to develop the queer potentialities of the myth. Britten centred his adaptation around the figure of Phaedra and, therefore, around the theme of love considered as deviant. He selected the episodes from Racine's tragedy where Phaedra confesses her guilt to her nurse, to Hippolytus, to herself, and to Theseus, as he wanted to focus on Phaedra's difficulty to out her feelings because of the social condemnation of them. Differently from Britten, Bussotti wanted to give prominence to homoerotic desire in his adaptation of the myth rather than to Phaedra's grievous inner conflict; Henze, on the other hand, chose the myth of the Cretan queen to focus on the figure of her stepson, and to deal with the theme of the heterosexual procreative love's refusal.

The examination of the musical language of these three works has revealed that the aspects of the musical scores that concur in defining a homosexual dramaturgy are barely perceivable to the audience. Instead, they will most likely become apparent to a scholar actually

39 On queerness in other Henze's operas see: F. Marsico, Il poeta e la sua elegia del desiderio inappagato, "La Fenice prima dell'opera" (season 2013-2014), 4, pp. 11-30; ead., Il conflitto fra sogno e realtà in Der Prinz von Homburg di Hans Werner Henze, in: N. Amendola, G. Sciommeri (eds.), Conflitti, vol. 2: Arte, Musica, Pensiero, Società, Roma 2017, pp. 137-147; F. Marsico, Boulevard Solitude di Hans Werner Henze. Una lettura intertestuale del libretto, "Rassegna musicale Curci" LXVII (2014), 3, pp. 37-43. 
looking for them. In the three works at issue, the discourse about gayness namely takes shape through the interplay of numerous aspects. The elaboration of the literary sources, the organization of the libretto, the characters' definition, and the mise-en-scène, together with the music, put the myth into that very perspective. Moreover, the research has highlighted that the three composers came to understand semantic potentials of the myth that had not yet been investigated in its previous musical elaborations, and that they developed these in a way as to give utterance to their own gay identity.

This study makes a contribution to the knowledge of the expression of homosexuality in the music of the 2oth century. However, further studies on this topic in dialogue with other disciplines, with the aim to define the features of the queer musical aesthetics in the 2oth century, would be desirable. Brett, twenty years ago, highlighted the importance of such survey, when he wrote:

In the 2oth century, homosexuality becomes such a tremendous presence in music that its obliteration by silence constitutes one of the most crushing intellectual indictments of positivistic musical scholarship..$^{40}$

40 P. Brett, Musicality, essentialism, and the closet, in: P. Brett, E. Wood, G. C. Thomas (eds.), Queering the Pitch, op. cit., pp. 9-26: 15. 


\section{Abstract}

Three musical adaptations of the myth of Phaedra, in which the wife of King Theseus of Athens desperately falls in love with her stepson Hippolytus, were composed in the second half of the twentieth century by three homosexual composers: the dramatic cantata Phaedra for mezzosoprano and small orchestra (1976) by Benjamin Britten (1913-1976) after a text by the American poet Robert Lowell, the opera Le Racine: pianobar pour Phèdre (1980) by Sylvano Bussotti (1931-) after a libretto drafted by the composer himself and consisting of a prologue, three acts, and an intermezzo, and, last but not least, the two-act concert opera Phaedra (2007) by Hans Werner Henze (1926-2012) after a libretto by the German poet Christian Lehnert.

The aim of this paper is to prove that the three homosexual composers chose a myth about an incestuous-and thus censored-love in order to represent homoerotic desire, labelled as deviant by the coeval heteronormative society and hence condemned by it.

The study sheds light on the aspects of the most famous literary elaborations that affect gay sensibility, and on how the three composers experienced their homosexuality and gave utterance to it in their other works. The analysis of the three works at issue demonstrates that the discourse about gayness takes shape through the interplay of numerous aspects. The elaboration of the literary sources, the organization of the libretto, the characters' definition, and the mise-en-scène, together with the music, put the myth into that perspective.

\section{Keywords}

Benjamin Britten, Sylvano Bussotti, Hans Werner Henze, homosexuality, myth of Phaedra 


\section{Abstrakt}

\section{Mit o Fedrze w muzyce a teoria queer}

Trzy adaptacje mitu o Fedrze - żonie króla Aten Tezeusza, która fatalnie zakochuje się w swoim pasierbie Hipolicie - zostały skomponowane $\mathrm{w}$ drugiej połowie XX wieku przez trzech kompozytorów-homoseksualistów. Były to: kantata dramatyczna Fedra na mezzosopran i małą orkiestrę (1976) Benjamina Brittena (1913-1976) do tekstu amerykańskiego poety Roberta Lowella; następnie opera Le Racine: pianobar pour Phèdre (1980) Sylvano Bussottiego (ur. 1931) do libretta naszkicowanego przez samego kompozytora i składającego się z prologu, trzech aktów i intermezza, oraz dwuaktowa opera koncertowa Phaedra (2007) Hansa Wenera Henzego (1926-2012) do libretta niemieckiego poety Christiana Lehnerta.

Celem tego artykułu jest udowodnienie, że trzech homoseksualnych kompozytorów wybrało mit o kazirodczej - a przez to zakazanej miłości, aby ukazać homoerotyczne pragnienie uznawane przez współczesne im społeczeństwo heteronormatywne za zwyrodniałe i przez to potępiane. Niniejsza praca rzuca światło na ukazane w najsłynniejszych literackich opracowaniach aspekty wpływające na wrażliwość gejów, oraz wykazuje, jak trzech twórców pojmowało swoją seksualność i wyrażało ją w swoich kompozycjach. Analiza trzech utworów pod tym względem wykazuje, że dyskurs o homoseksualizmie kształtuje się poprzez wzajemne oddziaływanie na siebie różnych aspektów dzieła, które obejmują opracowywanie źródeł literackich, uporządkowanie libretta, charakterystykę bohaterów czy inscenizację dzieła, które wraz z muzyką składają się na jego określoną interpretację.

\section{Słowa kluczowe}

Benjamin Britten, Sylvano Bussotti, Hans Werner Henze, homoseksualizm, mit o Fedrze 


\section{Bibliography}

Attinello P., Osmond-Smith D., Gay Darmstadt. Flamboyance and rigour at the summer courses for new music, "Contemporary Music Review" xxvi (2007), 1, pp. 105-114.

Barthes R., Sur Racine, Paris 1963.

Bettini M., L'incesto di Fedra e il corto circuito della consanguineità, "Dioniso" (2002), 1, pp. 88-99.

Borghetti V., Fedra. La Grecia modernista di d'Annunzio e di Pizzetti, in: Sandrini G., Natale M. (eds)., Gli antichi dei moderni. Dodici letture da Leopardi a Zanzotto, Verona 2010, pp. 139-168.

Brett P., Are you musical? Is it queer to be queer? Philip Brett charts the rise of gay and lesbian musicology, "The Musical Times" CIIIV (1994), 1816, pp. 370-376.

Brett P., Britten and Grimes, "The Musical Times" CxviII (1977), 1618, pp. 955-1000.

Brett P., Music and Sexuality in Britten. Selected Essays, Berkeley-Los Angeles-London 2006.

Brett P., Musicality, essentialism, and the closet, in: Brett P., Wood E., Thomas G. C. (eds.), Queering the Pitch. The New Gay and Lesbian Musicology, 2nd ed., New York 2006, pp. 9-26.

Brett P., Piano four hands. Schubert and the performance of gay male desire, "19th-Century Music" XII (1997), 2, pp. 149-176.

Brett P., Wood E., Thomas G. C. (eds.), Queering the Pitch. The New Gay and Lesbian Musicology, 2nd ed., New York 2006.

Bridcut J., Britten's Children, London 2006.

Britten B., Phaedra. Dramatic Cantata for Mezzo-Soprano and Small Orchestra Op. 93. Words from a Verse Translation of Racine's Phèdre by Robert Lowell (score), London 1992.

Bussotti S., La Passion selon Sade. Mystère de chambre avec Tableaux vivants, précédé de Solo avec un couple Rara et suivi une autre Phrase à trois (score), Milano 1966.

Butler J., Bodies That Matter. On the Discursive Limits of "Sex", New York 1993.

Butler J., Gender Trouble. Feminism and the Subversion of Identity, New York 1990. 
Carpanelli F., Frammenti tragici. Euripide e l'incesto, in: Guidorizzi G. (ed.), Legami di sangue, legami proibiti. Sguardi interdisciplinari sull'incesto, Roma 2007, pp. 31-52.

Dalla Valle D., Il mito cristianizzato. Fedra/Ippolito e Edipo nel teatro francese del Seicento, Bern 2006.

Dalla Valle D., Classicità della Phèdre di Racine, in: Uglione R. (ed.), Atti delle Giornate di studio su Fedra (Torino, 7-9 maggio 1984), Torino 1985, pp. 241-254.

Daolmi D., Henze ovvero della coerenza (interview with the composer), "Babilonia" 89 (1991), pp. 42-44.

Daolmi D., Senici E., "Lomosessualità è un modo di cantare". I contributi queer all'indagine sull'opera in musica, "Il Saggiatore musicale" VII (2000), 1, pp. 137-178.

De Lauretis T., Queer Theory. Lesbian and Gay Sexualities. An Introduction, "Differences" III (1991), 2, pp. III-XVIII.

De Sanctis F., La Fedra di Racine, in: Contini G. (ed.), Scelta di scritti critici e ricordi, Torino 1969, pp. 71-91.

Di Benedetto V., Euripide. Teatro e società, Torino 1992.

Fusini N., La Luminosa. Genealogia di Fedra, Milano 1990.

Giancotti F., Poesia e filosofia in Seneca tragico. La Fedra, in: Uglione R. (ed.), Atti delle Giornate di studio su Fedra (Torino, 7-9 maggio 1984), Torino 1985, pp. 143-212.

Goretti G., Giartosio T., La città e l'isola. Omosessuali al confino nell'Italia fascista, Roma 2006.

Guglielminetti M., La Fedra di d'Annunzio, e altre Fedre, in: Uglione R. (ed.), Atti delle Giornate di studio su Fedra (Torino, 7-9 maggio 1984), Torino 1985, pp. 33-54.

Harris E. T., Handel as Orpheus. Voice and Desire in the Chamber Cantatas, Cambridge MA 2001.

Henze H. W., Die Schwierigkeit, ein bundesdeutscher Komponist zu sein. Neue Musik zwischen Isolierung und Engagement (interview with H. Kolland), in: Henze H. W., Musik und Politik. Schriften und Gespräche 1955-1984, new ed., München 1984, pp. 300-331: 323.

Henze H. W., Reiselieder mit böhmischen Quinten. Autobiographische Mitteilungen 1926-1995, Frankfurt am Main 1996.

Hubbs N., The Queer Composition of America's Sound. Gay Modernists, American Music, and National Identity, Berkeley 2004. 
Kallberg J., Chopin at the Boundaries. Sex, History, and Musical Genre, Cambridge-London 1996.

Kildea P., Benjamin Britten. A Life in the Twentieth Century, London 2013. Kosofsky Sedgwick E., Epistemology of the Closet, Berkeley 1990.

Kramer L., Franz Schubert. Sexuality, Subjectivity, Song, Cambridge 1998.

Kramer L. (ed.), "19th-Century Music" XVII (1993), 1: Schubert. Music, Sexuality, Culture.

Labé L., Euvres complètes, ed. by E. Giudici, Genève 1981.

Longo O., Ippolito e Fedra fra parola e silenzio, in: Uglione R. (ed.), Atti delle Giornate di studio su Fedra (Torino, 7-9 maggio 1984), Torino 1985, pp. 79-96.

Lowell R., Racine's Phèdre. Phaedra, Faber 1961.

Marsico F., Il conflitto fra sogno e realtà in Der Prinz von Homburg di Hans Werner Henze, in: Amendola N., Sciommeri G. (eds.), Conflitti, vol. 2: Arte, Musica, Pensiero, Società, Roma 2017, pp. 137-147.

Marsico F., Una lettura queer del mito di Fedra. Gli adattamenti di Britten, Bussotti e Henze, PhD dissertation, University of Pavia 2016.

Marsico F., Boulevard Solitude di Hans Werner Henze. Una lettura intertestuale del libretto, "Rassegna musicale Curci" LXviI (2014), 3, pp. 37-43.

Marsico F., Il poeta e la sua elegia del desiderio inappagato, "La Fenice prima dell'opera" (season 2013-2014), 4, pp. 11-30.

Mattiacci S., Da Apuleio all'Aegritudo Perdicae. Nuove metamorfosi del tema di Fedra, in: Degl'Innocenti Pierini R., Lambardi N., Magnelli E. et al. (eds.), Fedra. Versioni e riscritture di un mito classico. Atti del convegno AICC (Firenze, 2-3 aprile 2003), Firenze 2007, pp. 131-156.

McClary S., Feminine Endings. Music, Gender and Sexuality, 2nd ed., Minneapolis-London 2002.

Mitchell D., Reed P. (eds.), Letters from a Life. The Selected Letters of Benjamin Britten 1913-1976, vol. 2, London 1998.

Nuzzo G., La Dea Bianca e il Cacciatore. Fedra tra Seneca e d'Annunzio, in: Blancato M., Nuzzo G. (eds.), La tragedia romana. Modelli, forme, ideologia, fortuna, Palermo 2007, pp. 77-107.

Orlando F., Due letture freudiane. Fedra $e$ Il misantropo, Torino 1990.

Paduano G., Ippolito. La rivelazione delleros, in: Uglione R. (ed.), Atti delle Giornate di studio su Fedra (Torino, 7-9 maggio 1984), Torino 1985, pp. 55-77. 
Raboni G., Lo statuto della reticenza, in: Uglione R. (ed.), Atti delle Giornate di studio su Fedra (Torino, 7-9 maggio 1984), Torino 1985, pp. 257-261.

Réage P., Histoire d'O, preface by J. Paulhan, Paris 1954.

Rosati G., Forma elegiaca di un simbolo letterario. La Fedra di Ovidio, in: Uglione R. (ed.), Atti delle Giornate di studio su Fedra (Torino, 7-9 maggio 1984), Torino 1985, pp. 113-131.

Scarcella A. M., Gli amori di Fedra fra tragedia e romanzo, in: Uglione R. (ed.), Atti delle Giornate di studio su Fedra (Torino, 7-9 maggio 1984), Torino 1985, pp. 213-236.

Scarlini L. (ed.), Corpi da musica. Vita e teatro di Sylvano Bussotti, Firenze 2010.

Schwartz M. (ed.), Homosexuelle im Nationalsozialismus. Neue Forschungsperspektiven zu Lebenssituationen von lesbischen, schwulen, bi-, trans- und intersexuellen Menschen 1933 bis 1945, München 2014. Snell B., Die Entdeckung des Geistes. Studien zur Entstehung des europäischen Denkens bei den Griechen, 4th ed., Göttingen 1975.

Solie R. A. (ed.), Musicology and Difference. Gender and Sexuality in Music Scholarship, Berkeley-Los Angeles-London 1993.

Solomon M., Franz Schubert and the peacocks of Benvenuto Cellini, "19th-Century Music" XII (1989), 3, pp. 193-206.

Spitzer L., Linguistics and Literary History. Essays in Stylistics, 2nd ed., Princeton 1967.

Starobinski J., L’oil vivant. Corneille, Racine, La Bruyère, Rousseau, Stendhal, Paris 1999.

Vernant J.-P., Vidal-Naquet P., Mythe et tragédie deux, Paris 1986.

Vernant J.-P., Vidal-Naquet P., Mythe et tragédie en Grèce ancienne, Paris 1972.

Weeks J., Coming Out. Homosexual Politics in Britain from the Nineteenth Century to the Present, London-New York 1990.

Whitesell L., Britten's dubious trysts, "Journal of the American Musicological Society” (2003), 66, pp. 637-694. 